\title{
RELATIONSHIP OF VESTED ASSETS TO WAR CLAIMS
}

\author{
Matcolm S. Mason*
}

During the period of hostilities between the United States and Germany, property in the United States in which there were German interests was blocked or taken under supervision or vested. The act of vesting constituted a transfer of title from the former owner to the United States. 1 The ultimate disposition of such vested property, however, remained in doubt for some time. Early in the war it was argued, for example, by John Foster Dulles ${ }^{2}$ that title was taken only as a precautionary measure for the duration of the war. Other authorities argued that the ultimate disposition remained for the Congress to determine, and urged on grounds of assertedly established principles of international law and of policy and expediency that no confiscation of such property should occur.

This problem had arisen in very similar terms during and after World War I. German property in the United States was then seized and held for ultimate disposition as the Congress might direct. ${ }^{3}$ The Alien Property Custodian originally conceived of himself as a trustee. ${ }^{4}$ Later he became persuaded that the property should be forever removed from the control of the former enemies who had held it, and he undertook a campaign of Americanization by sale to American interests of vested property. ${ }^{5}$ With respect to the proceeds of such sales, that which had been the property of the German government itself or of the German ruling family was retained on account of war claims. ${ }^{6}$ Substantial portions of the proceeds of the vesting of private German property were made returnable by postwar legislation. ${ }^{7}$ The remainder served as security for the payment of certain war claims of American nationals against Germany. ${ }^{8}$ In 1934, when it became clear that Germany would

- A.B. 1930, LL.B. 1934, Columbia University. Member of the firm of Telsey, Lowenthal, Rothenberg \& Mason, New York. Formerly Special Assistant to the Attorney General and Chief, Legal Branch, Office of Alien Property, Department of Justice. Member of the bar of the United States Supreme Court and the New York bar. Author, The Utility of Consideration-A Comparative View, $4 \mathrm{I}$ CoL. L. Rev. 825 (194I); Conflicting Claims to German External Assets, 38 Geo. L. J. I7I (1950); and other articles bearing upon comparative law and alien property. The views expressed in this article are of course the author's, and do not necessarily represent the views of the Office of Alien Property.

${ }^{1}$ Cummings v. Deutsche Bank, 300 U. S. Ix 5, I20-12I (1937); United States v. The Antoinetta, 153 F.2d 138 (3d Cir. 1945), cert. denied, 328 U. S. 863 (1946).

'The Vesting Powers of the Alien Property Custodian, 28 Cornelt L. Q. 245 (I943).

${ }^{3}$ Section 12, Trading With the Enemy Act, 40 STaT. 460 (1918), 50 U. S. C. App. \$12 (1946).

- Sec Report of Alien Property Custodian 2-3 (H. R. Doc. No. 840, 65th Cong., 2d Sess.) (January 18, 1918); Report of Alien Property Custodian 9 (S. Doc. No. 435, 65th Cong., 3d Sess.) (March I, 1919).

EReport of Alien Property Custodian 15, 239 (March I, I919); Section I2, Trading with the Enemy Act, as amended March 28, x918, 40 Stat. 60, 50 U. S. C. App. $\$$ r2 (r946).

'Section 25(d), Trading with the Enemy Act, added by Settlement of War Claims Act of 1928; 45 STAT. 268 (1928), 50 U. S. C. App. $\$ 25$ (d) (r946).

TSection 9 (b), especially 9 (b) (9), (10), (12), (r3), (14), and (x6), 9(h), 9(j), 9(m).

${ }^{8}$ Settlement of War Claims Act of I928, Sections 2(a), 2(b), 2(d), 4, and ro, 45. STAT. 254, 260, 268. 
not honor these war claims, further returns were cut off by Public Resolution Number 53, Seventy-Third Congress, subject to certain exceptions which the President might make and which have been narrowly defined in favor of persons having a non-hostile character. ${ }^{9}$

The right to retain German property as security for war claims was expressly provided in the Treaty of Berlin ending World War I between the United States and Germany. These provisions are also found in the Treaty of Versailles. ${ }^{10}$

In World War II, the question of the ultimate disposition of vested assets broke out afresh. The opposing points of view are perhaps most persuasively stated in a symposium appearing in Law and Contemporary Problems, Winter-Spring 1945. Several outstanding authorities had argued that confiscation of enemy property would be morally wrong, inconsistent with traditional international law precedents and with established American policy, and would be inexpedient. This point of view is eloquently stated and the authorities supporting it are gathered in Otto C. Sommerich's "A Brief Against Confiscation."11 The opposing point of view is cogently set forth in Seymour J. Rubin's “'Inviolability' of Enemy Private Property."12 Mr. Rubin's article concludes:

It is suggested that the answer is clear and that the conclusion is compelling that enemy property assets should, not only for reasons of expediency, but also for reasons of justice, be utilized for the payment or the securing of the enemy's reparation or similar debts.

The debate was closed by an article by Congressman Gearheart, "Post-War Prospects for Treatment of Enemy Property,"13 advocating a program for the disposition of enemy alien assets broadly following Mr. Rubin's suggestions. This program set the general pattern followed by legislation later enacted.

External investments are no longer private property. A country uses its nationals' external investments as an instrument of national policy and as part of its national foreign exchange resources. At the most, the nominal holding of external investments is tolerated at sufferance as a deliberate and watchful decision of policy. A distinguished Dutch lawyer has declared: "The private owner is nowadays nothing but a trustee on behalf of his Government."14 This has most conspicuously been true in the case of Germany which, even before the event of the Nazi regime, established governmental controls over external investment that completely denatured their ostensibly private character..$^{15}$ 508.2.

- Exec. Order No. 6981 of March 2, 1935, and Exec. Order No. 7111 of July 22, 1935. 8 CFR 508.1,

${ }^{10}$ Public Resolution No. 8, 67th Cong., Ist Sess. (I921), 42 STAT. I05, \$\$2, 4, 5; 42 Stat. 1939, 1946 (1921); Treaty of Versailles, Art. 297.

II LAw \& Contemp. Prob. 152 (Winter-Spring, 1945).

${ }^{12} 1$ d. at 166.

${ }^{15}$ Prof. Mr. M. H. Bregstein, De confiscatie van vijandelijk vermogen in het licht van het deviesen. regiem, Nederlands Juristenblad, 21 October 1950, No. 35, pp. 737, 740.

${ }^{16}$ Statement of Heinrich Kronstein, then Special Attorney, Anti-trust Division, Department of lustice, and Professor of Comparative Law, Georgetown University Law School, in Hearings before the 
The traditions that have grown up with respect to the enemy's private investments were established when property meant something different from what it means today, and when war meant something different from what it means today.

I find myself in agreement, therefore, with Mr. Rubin's rejection of the notion of inviolability. His further conclusion, however, that enemy property should, after seizure, be devoted to the securing or paying of war claims has been rendered unrealistic, it seems to me, by a post-war situation that could not reasonably have been anticipated when his article was written.

In World War I, the Alien Property Custodian seized enemy property amounting to about six hundred million dollars. If a large portion of this had not been returned as a matter of grace, this property would have covered all of the claims allowed. ${ }^{16}$

In World War II, a smaller mass of property has been seized, while the war claims are probably much greater. ${ }^{17}$ This fact is one of the bases of Mr. Rubin's argument. But we must set beside these figures the still greater sum that the United States finds itself compelled to expend each year for the support of occupied Germany. The United States must spend each year many hundreds of millions to preserve a defeated Germany from famine and disease, to permit even a bare minimum of rehabilitation or, in line with present policy, to establish economic conditions in Germany on a level much higher than that of bare subsistence. ${ }^{18}$

Senate Committee on Patents on S. 2303 and S. 2491, Pt. 3, 77th Cong., 2d Sess. 1334-1354 (1942). Roe, War Measures, the Alien Property Custodian, and Patents, 25 J. PAT. OFF. Soc'y 692, 704-705 (I943).

10 The awards of the Mixed Claims Commission, United States and Germany, totaled about \$1 81,000,000 in principal. With interest to date of payment, or, if unpaid, to September 30, 1940, they totalled about $\$ 355,000,000$. Final Report of Acting Agent of the United States beforl the Mixed Claims Commission, United States and Germany 93 (i94I); Report of War Claims Commission i i (I950). Enemy property seized in World War I was valued at $\$ 534,000,000$. Income on this property to April, r942, amounted to about $\$ 134,000,000$, a total of $\$ 668,000,000$. Of this amount there still remained in April, 1942, about $\$ 70,000,000$ in government hands. ANnual Report, Office of AlieN Property Custodian I42 (1944). Additional funds, however, had been supplied to the German Special Deposit Account (Dawes Plan payments, Debt Settement Agreement payments, appropriations), and about $\$ 160,000,000$ had been paid on account of the awards. REPORT OF THE WAR CLAMM Commisston II (1950).

17 The net equity vested was valued at about $\$ 416,000,000$ as of June 30, 1949. REPORT OF OFFICE of Alien Property 8-12 (1949). Harold I. Baynton, Assistant Attorney General, Director, Office of Alien Property, has estimated that this represents about $\$ 170,000,000$ in excess of necessary reserves for claims and suits. Hearings before a Subcommittee of Committee on Interstate and Foreign Commerce on H. R. 6808, 700I, and other bills, 8rst Cong., 2d Sess. 60-62 (1950). The immediate program of the War Claims Commission, it has been estimated, will require about \$150,000,000. Statement of Daniel F. Cleary, Chairman, War Claims Commission, in Hearings, stipra, at 31-32; REPoRT of War Claims CoMMisston 58 (1950). This represents, however, only a first class of claimants. The Commission is charged with recommending further proposals for payment of war claims. War Claims Act of 1948, section 8, 62 Stat. 1245, 50 U. S. C. App. $\$ 2007$ (Supp. 1950). Property damage, for example, is as yet unprovided for. Although it is difficult to estimate the amount of war claims that will be held valid, early official estimates were very high. See, for example, statement of Ansel F. Luxford, Assistant General Counsel, Treasury Department, Hearings before Subcommittee No. 1 of the House Committee on the Judiciary on H.R. 4840, 78th Cong., 2d Sess. $103-106$ (1944); letter of D. W. Bell, Acting Secretary of the Treasury, set out in Mr. Luxford's statement; letter of James E. Markham, Alien Property Custodian, January 8, 1946, Hearings before a Subcommittee of the Senate Committee on the Judiciary on S. 1322, 79th Cong.; 2d Sess. 5-8 (1946); statement of Seymour J. Rubin, Deputy Director of the Office of Economic Security Policy, Department of State, in Hearings on S. 1322 , supra, at 63. Cf. Rubin, supra note 12, at 179.

19 See, e.g., OfFice of the UNITED States High CoMmissioner For Germany, First Quarterly 
To seize German property with one hand and to argue for its devotion to a particular purpose while, with the other hand, paying out of our own pockets these very much larger sums, becomes an unrealistic bookkeeping. If enemy assets must be devoted to some particular goal, I would suggest that it were much more reasonable to recognize that the damages done by Germany will never be made whole; that valid war claims will never be paid; that compensation for war claims to the extent that it is allowed must come, if at all, from the American Treasury; and to devote all German assets in this country directly to the relief of Germany, which we have, in fact, undertaken. But I do not feel that anything is gained by naming a destination for these assets. The assets should be seized, they should be retained, the ultimate proceeds should be paid into the United States Treasury, and the United States should frankly recognize that out of its undifferentiated funds it must both make whole such individual war claims as it feels should be recognized and support the economy of Germany to the extent that national policy requires. The contrary course represents a bookkeeping device apt to mislead the unsophisticated, and justifiable, if at all, only because of some demonstrable efficiency that it produces in the administration of government moneys. A review of the course actually followed with respect to these funds will show that our present procedure does not lead to efficiencies.

This discussion will be primarily concerned with German external assets. In order to set the discussion in its context, however, I shall review briefly the situation with respect to the external assets of other enemy countries.

Italy. Italian assets were originally vested like other enemy assets in this country. When Italy become a cobelligerent, the Alien Property Custodian stopped vesting additional Italian assets which remained frozen. However, the peace treaty with Italy, executed February 10, 1947, makes special provision for reparation to be paid to the Soviet Union and to the countries principally injured by Italian actionAlbania, Ethiopia, Greece, and Yugoslavia (Article $74 \mathrm{~A}$ and B). The other United Nations were to satisfy their reparation claims out of Italy's external assets within their jurisdiction (Article $74 \mathrm{D}$ and Article 79). Italy agreed to compensate its nationals for the loss of such property (Article $74 \mathrm{E}$ and Article 79-3). The external assets authorized by the treaty to be retained by each of the United Nations were limited to the amount of claims against Italy. Thus; the treaty explicitly recognizes the principle of the application of external assets to war damage claims on the basis of a commitment for domestic reimbursement of the enemy's own nationals. Shortly after the treaty was signed, and before it became effective, a further economic settlement was made by the United States with Italy, under which the United States waived a substantial part of its own claims against Italy and a specific fund was

Report on Germany 23 (r949); Commtttee of European Economic Cooperation, General Report I 6 (Dep't State Publication No. 2930, European Series 28, I947); United States Economic Polict Tostard Germany 38-39 (Dep't State Publication No. 2630, European Series 15 (No Date)). 
provided by Italy to meet the war damage claims of private persons. ${ }^{18}$ Thereupon Italian frozen assets were unblocked (General License No. 95, as amended August 29, 1947), and the vested assets of Italian nationals became in general returnable under the provisions of Section 32 of the Trading with the Enemy Act, as amended by the Act of August 5, 1947..$^{20}$

Bulgaria, Hungary, Rumania. The treaties with the three satellite countries, Bulgaria, Hungary, and Rumania, which were signed February 10, 1947, similarly, in addition to reparation provisions in favor of certain specific countries, also expressly authorize the United Nations to retain the external assets within their jurisdiction of the three enemy satellites within the limits of war claims, and contain express commitments by the satellites to compensate their own nationals (Bulgaria, Articles 21 and 25; Hungary, Articles 23 and 29; Rumania, Articles 22 and 27.) The vesting of property of the satellite countries was halted on the coming into force of these treaties (September 15, 1947), in spite of the express treaty authorization for vesting. ${ }^{21}$ 'The satellite countries, however, failed to live up to their treaty obligations and a tighter freezing program was recently put into effect, carrying with it a suggestion that the authority granted by the treaty to vest and retain external assets might, if necessary, be invoked. ${ }^{22}$

Japan. The situation with respect to Japan is somewhat less definite. Unlike the satellite countries, there is no peace treaty as yet, and unlike Germany, there is no reparation agreement reflecting United Nations policy in an unambiguous way. There are indications, however, that Japanese external assets are likely to be treated substantially like German assets. The Department of State has proposed a treaty under which the Allied Powers would in general hold Japanese property within their territory. ${ }^{23}$ Section 39 of the Trading with the Enemy Act expressly prohibits the return of vested Japanese property, as well as vested German property, and it provides that the net proceeds of such property shall be devoted to the payment of certain specified categories of war claims and of such others as may later be designated, apparently without applying Japanese assets to the satisfaction of war claims against Japan specifically.

Special provision is made with respect to the Philippines. The statute creating

${ }^{10}$ The agreement, referred to as the "Lombardo Agreement," is described in Office of Alien Property Annul Report 5-7 (1948); Report of Senate Foreign Relations Commitiee on S. J. REs. 138 (8oth Cong., Ist Sess. (1949)).

${ }^{20} 6$ I STAT. 784 (1947), 50 U. S. C. App. $\$ 32$ (Supp. 1950).

${ }^{21} \mathrm{I}$ do not find any formal announcement of this policy. It is reflected, however, for example, in the letter of John W. Snyder, Chairman, National Advisory Council on International Monetary and Financial Problems, to Arthur H. Vandenberg, Chairman, Senate Foreign Relations Committes, of February 2, I948, which states: "Thus, German and Japanese assets will be transferred [to the jurisdiction of the Office of Alien Property] and vested. Hungarian, Roumanian, and Bulgarian assets will be transferred [to the jurisdiction of the Office of Alien Property] and will remain blocked until a settlement of war claims with these countries is made."

${ }^{22}$ See Regulations of the Office of Alien Property, sec. 5 xr.132a, revoking General License $32 a$ ( 15 F. R. 1029, February 25, 1950), Department of Justice Press Release of February 25, 1950.

20 Department of State Press Release No. I 80 of November 24, 2950. 
the Philippine War Damage Commission ${ }^{24}$ expressly. contemplates that reparation will be received from Japan. It authorizes the Commission to compensate for certain categories of property damage caused by the Japanese in the Philippines. The source of this compensation is a fund of four hundred million dollars appropriated out of the United States Treasury, and it is provided that reparation received from Japan on account of Philippine war losses is to be used first to reimburse the Treasury for this fund. Presumably, some portion of Japanese external assets seized by the United States will be credited to this fund. The provision for the Philippine War Damage Commission is particularly significant, since it indicates how reparation receipts may be treated as devoted to satisfaction of war damage claims without creating the specific and direct tie-up which we shall see has been an unfortunate feature of the general statute on this subject, the War Claims Act of $1948 .^{25}$

Germany. The principle of the seizure of German enemy assets and their devotion to the partial satisfaction of war claims was established by a series of agreements among the United Nations, culminating in the Paris Reparation Agreement. Each of the signatory countries, including the United States, there agreed upon the shares that they would take of various categories of German reparation. Included in these shares were to be the German enemy assets within the jurisdiction of each signatory country which each agreed to hold or dispose of in manners designed to preclude return to German ownership or control. These external assets were to be charged by each country against its reparation share.

In the Paris Agreement, each signatory country agreed that its share would be regarded "as covering all its claims and those of its nationals against the former German Government and its Agencies of a governmental or private nature arising out of the war (which are not otherwise provided for)." Thus by international agreement German external assets represent a portion of the funds which each country will look to for partial satisfaction of its war claims and those of its nationals. ${ }^{26}$ It may be supposed that a similar relationship will be established so far as Japanese external assets are concerned. ${ }^{27}$

The principle established in the Reparation Agreement was confirmed by the War Claims Act of I948, section I2 of which adds to the Trading with the Enemy Act a new section, section 39, expressly prohibiting any return of German or Japanese assets or the payment of compensation therefor, and directing that the net proceeds remaining upon the completion of administration, liquidation, and disposition pursuant to the provisions of the Act of any such property or interest therein shall be covered into the Treasury at the earliest practicable date.

\footnotetext{
24 Philippine Rehabilitation Act of 1946, 60 Star. r28, 50 U. S. C. App. \$\$175r-r806 (r946).

${ }^{25} 62$ STAT. I240 (1948), 50 U. S. C. App. \$\$2001-2013 (Supp. 1950).

2a United States Economic Policy Toward Germany ro8, ir i (Dep't State Publication No. 2630, European Series 15, App. h, Pt. I, Arts. 2A, 6A.)

${ }^{37}$ See discussion of Japan, supra.
} 
Section $\mathrm{r}_{3}(\mathrm{a})$ of the War Claims Act of 1948 created on the books of the Treasury a trust fund, to be known as the War Claims Fund, consisting of all funds so covered into the Treasury. The War Claims Act authorizes certain payments from the War Claims Fund for specified classes of urgent war claims, and contemplates that any sums remaining in the fund should be the subject of recommendations to be made by the War Claims Commission.

When one of the predecessors of the bill that became the War Claims Act was proposed, the Department of Justice, charged with the administration of alien property, recommended against the direct linking of vested assets and war claims. The Attorney General commented in the following terms on this point:

Moreover, I suggest that provision for payment by specific appropriation is a more direct approach and would assure that any moral obligation of this Government to insure compensation to its nationals for war damages would not be dependent upon the uncertainties of ultimate financial settlement with enemy countries or ultimate realization on vested property. At the same time it should, of course, be borne in mind that the final net proceeds of vested German and Japanese property, as well as any sums received by this Government by way of reparation from those countries, will in fact ultimately constitute an offset against any sums appropriated for the payment of the war damage claims of American nationals, as well as some slight offset against the general cost of the war to the United States. This factor underscores the importance of a present congressional declaration, as herein recommended, that there be no return of vested property to Germany or Japan or their nationals.

Accordingly, it would seem appropriate that this legislation be broadened to provide that the proceeds of German and Japanese vested property should be covered into the Treasury after completion of the program of administration and allowance of claims required by the Trading with the Enemy Act, as amended, and that a specific declaration of congressional policy be made to the effect that the proceeds of such property should not be returned. ${ }^{28}$

The Bureau of the Budget concurred in this recommendation and stated that a proposed covering into the Treasury of the proceeds of vested property was in its view

... in keeping with good fiscal practice, and would make for simpler and faster administration of both enemy assets and American war claims than would the alternative concept of paying claims from the proceeds of enemy assets. ${ }^{29}$

The bill nevertheless passed with the provisions creating this direct relationship. The enactment of the bill in this form may well have been an inadvertence, in as much as the House Committee reporting on an earlier form of the bill had commented as follows:

Section I provides that the net proceeds be covered into the general fund of the

${ }^{28}$ Letter of the Attorney General, April $\mathrm{r}_{5}$, 1947, in Hearings before House Committee on Interstate and Foreign Commerce on H. R. 873 and other bills, 8oth Cong., rst Sess. 278, 280 (1947). Cf. id. at 299-300; $c f$. statement of John Ward Cutler, Acting General Counsel, Office of Alien Property, id. at $264-265$.

${ }^{30}$ Quoted in Report No. 976 on H. R. 4044 , 8oth Cong., Ist Sess. 3 (1947). 
Treasury as miscellaneous receipts. This provision is preferable to maintaining the identity of these funds by keeping them in a separate Treasury account. No useful purpose could be served by adopting such procedure. No legal or logical relationship exists as between the net proceeds resulting from the liquidation of vested enemy assets and any war claims against enemy governments which might be advanced and adjudicated in the future. ${ }^{30}$

The law has now been in effect for some two years, and it is possible to make some judgment as to the accuracy of the fears expressed in advance by the government agencies commenting on the bill.

One of the effects of the law as enacted has been to make the War Claims Commission, which is the principal agency charged with a responsibility for disbursements from the War Claims Fund, a spokesman for the groups of war claimants asserting a right to be satisfied out of the Fund. Obviously, with limited funds at its disposal, the War Claims Commission is faced with responsibility for difficult decisions. It would prefer to have at its disposal a larger fund. The Commission and the organized groups who expect to be beneficiaries of the Act tend to take a proprietary interest in the Fund. In consequence, on behalf of all applicants for the Fund, the War Claims Commission becomes in effect a pressure group with official status seeking the enlargement of the Fund. As a result, the Office of Alien Property becomes subjected to severe organized pressures for the completion of its task of liquidation at rates not consistent with the orderly discharge of its own duties.

The situation that results is illustrated by a pair of bills introduced by Messrs. Miles and Fernandez, both of New Mexico, directing the Office of Alien Property to turn over forthwith to the War Claims Fund one hundred and fifty million dollars. $^{31}$ These bills were introduced at a time when the Office of Alien Property did not hold liquid funds free and clear of claims already authorized by law in any sum approximating one hundred and fifty million dollars. ${ }^{32}$ Moreover, had these bills been enacted and complied with, they would have served no useful purpose since it was not possible for the War Claims Commission, proceeding even at a rate substantially in excess of the progress that could be reasonably forecast for it, to make awards that would require so large a fund within, say, a year's time. ${ }^{33}$ Nevertheless, these bills initially received the support of the War Claims Commission. ${ }^{34}$ The Office of Alien Property proceeded to advance to the War Claims Fund the sum of fifteen million dollars, and gave assurances that by the time more was

${ }^{30}$ Ibid.

${ }^{31}$ H. R. 7001 and H. R. 7030, 81st Cong., 2d Sess. (1950).

${ }^{32}$ Statement of Harold I. Baynton, Acting Director (now Assistant Attorney General), Office of Alien Property, in Hearings before a Stibcommittee of the House Committee on Interstate and Foreign Commerce on H. R. 6808, 70or and other bills, 81st Cong., 2d Sess. 60, 61, 62 (1950).

${ }^{33}$ Statement of Daniel F. Cleary, Chairman, War Claims Commission, in Hearings, supra note 32, at 3I; statement of Donald MacPhail, Office of the Director of the Bureau of the Budget, id. at $45-46$.

se Letter of Daniel F. Cleary, Chairman, War Claims Commission, in Hearings, supra note 32, at 8-9. 
needed it would be available. In the light of this, the Chairman of the War Claims Commission withdrew his support of the bills. ${ }^{35}$

This is an extreme example of a kind of problem that is constantly renewed in a number of less obvious respects. By private pressures on one side and Congressional pressures on the other, the War Claims Commission is made to feel responsible for seeing to it that "ample provision is made at any early date to take care of the claims" it expects to honor. ${ }^{36}$ Since the "provision" is a matter of bookkeeping and not of the real existence of funds, and since decision as to the funds rests with the Congress, the sense of responsibility is not rationally justified but humanly very understandable. The Department of Justice, on the other hand, "must insist that the orderly liquidation of vested property and discharge of responsibilities imposed on the Office of Alien Property by existing law not be hampered by unnecessarily precipitous disposition of funds which may be needed" in its program and are not yet needed by the War Claims Commission. ${ }^{37}$ The pressure by the War Claims Commission for the increase of the funds administered by it, and the resistances by the Office of Alien Property to unnecessary inroads on the funds administered by it, represent a form of governmental friction which takes up a great deal of energy, time, manpower, and generates heat but makes. no effective contribution to government.

The opposition created by the War Claims Act between the policy inclinations of the War Claims Commission and those of the Office of Alien Property reflects itself in another important respect. From time to time it becomes necessary for the Congress to consider amendments to the Trading with the Enemy Áct. These amendments are likely to affect the size of the ultimate fund applicable to war claims. For this reason, the War Claims Commission is one of the agencies whose views are consulted, and its almost unavoidable disposition is to recommend against any amendment to the law that might tend to diminish the fund ultimately available for war claims. As the War Claims Commission conceives its duty, it is obligated to insure at all times the sufficiency of funds to provide for payment in full of every valid claim given status by the War Claims Act of I948. This situation, it seems to me, is not conducive to sound legislative policy.

If, for example, an amendment is introduced on behalf of a group of non-hostile persons who have been caught by the rather sweeping terms of the Trading with the Enemy Act, the question for consideration should be whether there is any justification for the United States to seize the property of such persons, and not

${ }^{35}$ Letter of Peyton Ford, in Hearings, stipra note 32, at 7-8; statement of Donald MacPhail, id. at 43-44; statement of Daniel F. Cleary, id. at 32-33.

${ }^{38}$ Statement of Daniel F. Cleary, Hearings, supra note 32 , at 34. It is worthy of note that throughout this portion of his statement the Chairman of the Commission was being pressed to seek protection against action the Congress might later find appropriate. Cf. statement of Thomas H. Roberts, General Counsel, War Claims Commission, id. at 188. Compare also Mr. Cleary's statement on S. I292 and H. R. I848; id. at 290-295.

${ }^{37}$ Statement of Harold I. Baynton, Hearings, supra note 32, at 60. 
whether a release of the property will damage the fund. If the United States ought not in good conscience to seize the property in the first place, the fact that a release of the property could damage the fund is plainly irrelevant to any sound policy approach. Nevertheless this confusion repeatedly and inevitably arises as a result of the establishment of the War Claims Fund.

For example, a number of American women, who had lived in Germany during the Hitler regime and the war period and had acquired and exercised German citizenship, nevertheless were entitled by statute after the war to reclaim with retroactive effect their American citizenship. ${ }^{38}$ Whether their property, seized as enemy, should be returned to them raises important political questions that go to the root of our conceptions of American citizenship, of loyalty, of the purpose of enemy property seizures. Strongly opposing views can be held on this question by reasonable men. The issue, however, is one that ought to be decided in terms of the justification or lack of justification for seizing the property, and not in terms of a weighing of the amounts that might be subtracted from the fund by a return.

Similarly, when the question is presented whether property of Jewish families exterminated at Auschwitz and Buchenwald should continue to be held by the United States, the issue should be determined in terms of the justification or lack of justification for the seizure and not in terms of the effect of a return on the fund. If, as I believe, there is no justification for the United States to seize the property of Hitler's principal and most direct victims, ${ }^{30}$ it becomes immaterial whether a return of their property to their heirs or to a successor organization on behalf of other victims would substantially or only to a minor extent damage the fund available for war claims. Nevertheless, on questions of this kind the War Claims Commission becomes almost automatically a Cerberus protecting the fund. Its strong predisposition is to oppose any amendment of the law that might decrease the fund. In the case of the bill for the heirless property successor organization, which passed the Senate and was favorably reported on by the House Committee but did not pass the House, enactment of this legislation was seriously delayed by the circumstance that it was originally opposed by the War Claims Commission, and only later was this opposition withdrawn on the basis of representations that the sums involved would not exceed an outside estimate of three million dollars. ${ }^{10}$

${ }^{38} 54$ STAT. 1146 (1940), 8 U. S. C. $\$ 717$ (1946).

${ }^{38}$ Cf. Statement of General Lucius Clay on S. $60_{3}$, in Hearings, stipra note 32 , at 162 , 163 ; statement of Robert P. Patterson id. at 167 ; statement of George L. Warren, advisor on refugees and displaced persons, Bureau of United Nations Affairs, Department of State, id. at 175-176: ". . . the Department considers that the assets here involved are not the assets of enemies, but of enemies of our enemies, and to seize such assets would be morally reprehensible and unprincipled."

${ }^{10}$ Letter of Daniel F. Cleary, Chairman, War Claims Commission, January 10, 1950, in Hearings, supra note 32, at I52-I53; letter of Daniel F. Cleary, May 10, 1950, id. at 158-160; statement of Thomas H. Roberts, General Counsel, War Claims Commission, id. at I88-190, 194; statement of Robert P. Patterson, id. at $168-169$. In the Dutch system also, although it is recognized in theory that vested assets represent a source of partial payment of war claims, Bregstein, stipra note 14 , the procecds of vested assets are nevertheless paid into the general treasury and there is no direct connection between vested assets and war claims. 
Similarly, the dual national bill ${ }^{41}$ was first opposed by the War Claims Commission but the opposition was withdrawn on the proviso that property returned to dual nationals did not exceed a ceiling of five million dollars. ${ }^{42}$

I think the legislative histories of these bills reflect a basic confusion between two types of issues that should not be regarded as on the same plane. The first issue is whether particular items of property or classes of such property ought to be seized by the United States as enemy property and retained as reparation. The second issue arises only if the first question can be answered affirmatively. It is, which of the possible beneficiaries of a reparation fund which is certain to be inadequate to meet all claims, should be preferred and to what extent. Separation of these questions would make for clearer and wiser determinations of policy. The direct linking of these questions resulting from section 13 of the War Claims Act has created confusions of thought that should have been avoided.

It is of interest to consider what has been done with the like problem in other countries. I am informed that a system very similar to ours was adopted in France, where the proceeds of sequestered enemy property are to be paid into an autonomous fund, out of which allowed classes of war claims are to be paid. It is my impression that this system is one adopted as a necessary tightening up of the system established in World War I which failed to provide adequate safeguards to assure an efficient liquidation of enemy property. Moreover, the French program avoids one of the most disturbing features of the American program in that the autonomous fund consists not solely of proceeds of sequestered property, but also of certain other funds that may from time to time be paid into it, and it has the authority to borrow. 13 Accordingly, it does not create the excessive pressure found in the American system for immediate liquidation regardless of considerations of sound administration, and it does not create the opposition between those classes who may expect to be beneficiaries of the fund and those classes who have claims that property ought not to be included in the fund.

In the American situation, there are several additional sources of funds which might be covered into or advanced to the War Claims Fund. Among these may be

${ }^{11}$ Finally enacted as Public Law No. 859 (8rst Cong., 2d Sess.).

"Statement of Daniel F. Cleary, Chairman, War Claims Commission, in Hearings, supra note 32, at 288-293; cf. statement of Harold F. Reis, Acting Chief (now Chief), Legal Branch, Office of Alien Property, Department of Justice, $i d$. at 267 . To avoid misunderstanding, I should like to note that I did not favor the dual national legislation in the form it took. Nevertheless, the legislation was proposed on grounds of high policy. See, for cxample, statement of Raoul Berger, formerly General Counsel, Office of Alien Property Custodian, id. at 295ff. Whether the principles urged were sound or not does not seem to be affected by the number of dollars involved.

${ }^{3}$ Loi du 28 oct. 1946, Art. 5; Loi du 21 mars 1948. Cf. the analogous caisse autonome established in Belgium, Loi du 19 mai 1948; arrêté organique, 29 juin 1948. Here also the power of the fund to borrow money in the ordinary money markets, coupled with an assurance of funds from a variety of sources, removes the direct relationship between vested assets and war claims, which seems to me a source of difficulty in the American system. In the Dutch system also, although it is recognized in theory that vested assets represent a source of partial payment of war claims, Bregstein, supra note I4, the proceeds of vested assets are nevertheless paid into the general treasury and there is no direct connection betwcen vested assets and war claims. 
mentioned the proceeds of plant removals from Germany and the American share of the proceeds of German assets in neutral countries. Other possible sources of funds are mentioned by the War Claims Commission in its report to the President.44 Moreover, if the current rate of payment of allowed claims by the War Claims Commission should exceed the funds available in the War Claims Fund, it would appear to be better fiscal management for the funds to be advanced out of general Treasury funds within such limits as are suggested by the estimates of the funds that will ultimately be available out of enemy property than to require either a forced liquidation of vested assets or a delay in payment of justified war claims.

I have the distinct impression that many of those who have considered these problems have been misled by bookkeeping appearances. ${ }^{45}$ Property held by the Office of Alien Property is now property of the United States. It can be devoted to the partial satisfaction of war claims, or approximately equivalent amounts out of general funds can be so devoted. As the Assistant Attorney General in charge of Alien Property. had pungently said: "The government has the money only once, and cannot spend it twice." ${ }^{46}$ Arguments that suggest that it does not cost anything to use the vested assets can only mislead the Congress. It costs just as much to use those funds as to use-general Treasury funds, and we will have a much clearer picture of what we are doing if we recognize this.

4 Report of War Claims Commission 57-60, pt. IX (1950).

${ }^{15}$ Cf. e.g., S. 1072 for the relief of the Trust Association of $\mathrm{H}$. Kempner which sought payment out of World War I funds for a claim arising out of peacetime trading losses. The proponent of the bill repeatedly protested: "I am not taking it out of the Treasury of the United States. I would not be responsible for coming in here with a bill to take any money out of the Treasury of the United States to pay Kempner on this claim." Hearings before the Subcommittee of the Committee on the Judiciary, 8 rst Cong., Ist Sess. (r949). The same proponent, in supporting a similar measurc, H. R. 683, for the relief of Louise Peters Lewis (8Ist Cong., Ist Sess.), argued that "the bill takes nothing out of the United States Treasury. . . . Not a sou marquee, not a penny, not a mill." Report No. $7 x$ to accompany H. R. 683 , pp. 5, 7. The measure was passed, but vetoed. H. R. Doc. No. 370. This impression that it does not cost anything to spend vested assets seems to be reflected, for example, in the Hearings on H. R. 7001 and 7030, supra note 32, at 12-13, 32-33, 37 .

"Statement of Harold I. Baynton, Acting Director (now Assistant Attorney Gencral and Director), Office of Alien Property, Department of Justice, in Hearings, supra note 32, at $64-65$. 